\title{
Prenatal Ultrasound Detection of Congenital Gingival Granular Cell Tumor
}

\author{
Rebecca L. Hulett, MD, Richard A. Bowerman, MD, Terry Marks, RT, Andrew Silverstein, MD
}

Congenital gingival granular cell tumor in infants is a rare intraoral tumor of unknown histologic origin, but apparently related to the larger, but still uncommon, group of granular cell tumors seen in all age groups and multiple anatomic areas. We report the prenatal sonographic detection of such a lesion, imaged as a pedunculated extraoral mass extending from an intraoral source. Due to the potential for airway compromise, a prenatal diagnosis of a mass involving the airway should lead to delivery at a medical center prepared to handle that complication both temporarily, with airway maintenance, and ultimately, with surgical correction.

\section{CASE REPORT}

A 33-year-old gravida 2 para 1 was referred for a prenatal ultrasound (US) examination at approximately 38 weeks gestational age to assess the estimated fetal weight (EFW). Pertinent obstetrical history included a prior vaginal delivery of an 8-pound 8-ounce male, complicated by shoulder dystocia and postpartum hemorrhage. The US examination confirmed a gestation of 39 weeks based on biparietal diameter, head circumference, and femur length, with an EFW of $4270 \mathrm{~g}$. The amniotic fluid volume was normal. A lobulated mass was noted arising from the right side of the oral cavity and protruding out of the mouth (Fig. 1), with distortion of the lower face and lips. The tongue was displaced to the left and

Received June 21, 1990, from the Department of Radiology, University of Michigan Medical Center, Ann Arbor, Michigan. Revised manuscript accepted for publication August 29, 1990.

Address correspondence and reprint requests to Dr. Rebecca $L$. Hulett: University of Arizona Health Seiences Center, Tucson, AZ 85724. posteriorly. Bright internal echoes suggested calcification and a teratoma (epignathus) was suspected.

Amniocentesis revealed an L/S ratio of 6.07 and DSPC of $>600$. The patient underwent elective cesarean section with delivery of a 9-pound, 11-ounce female with Apgars of 7 and 9 at 1 and 5 minutes. The infant had a spontaneous cry and good respiratory effort. A large, pink/grey pedunculated rubbery mass protruding from the mouth appeared to arise from the superior alveolar ridge on the right (Fig. 2). The palate, tongue, and lips appeared grossly intact. To insure airway patency, the infant was electively intubated.

As a teratoma was still suspected, a cranial US examination

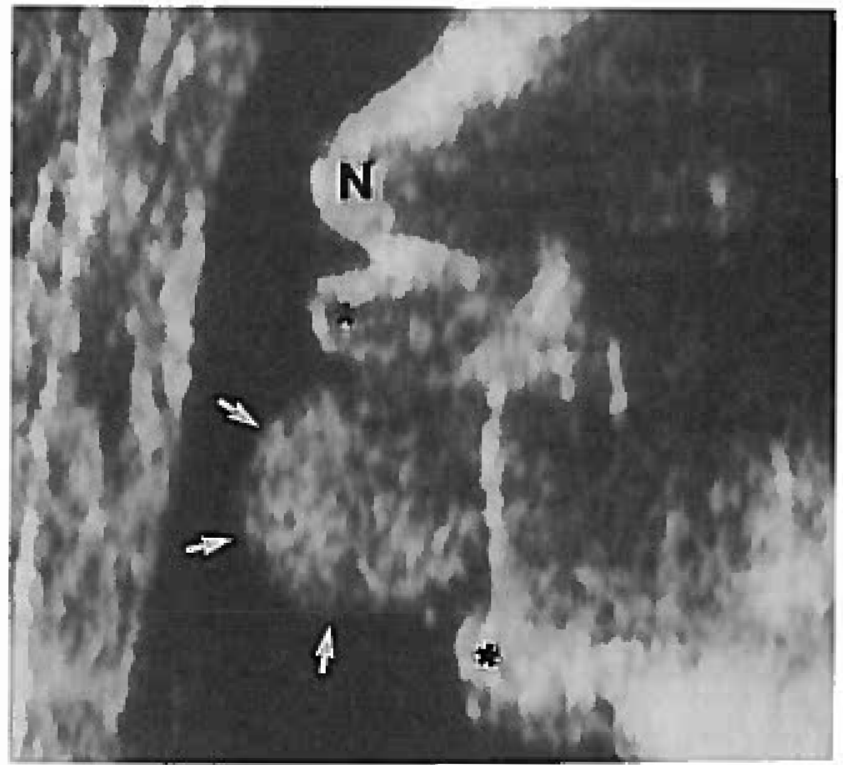

Figure 1 Midsagittal sonogram of the lower face shows the mass (arrows) protruding from the open mouth. N, nose; asterisks indicate lips. 


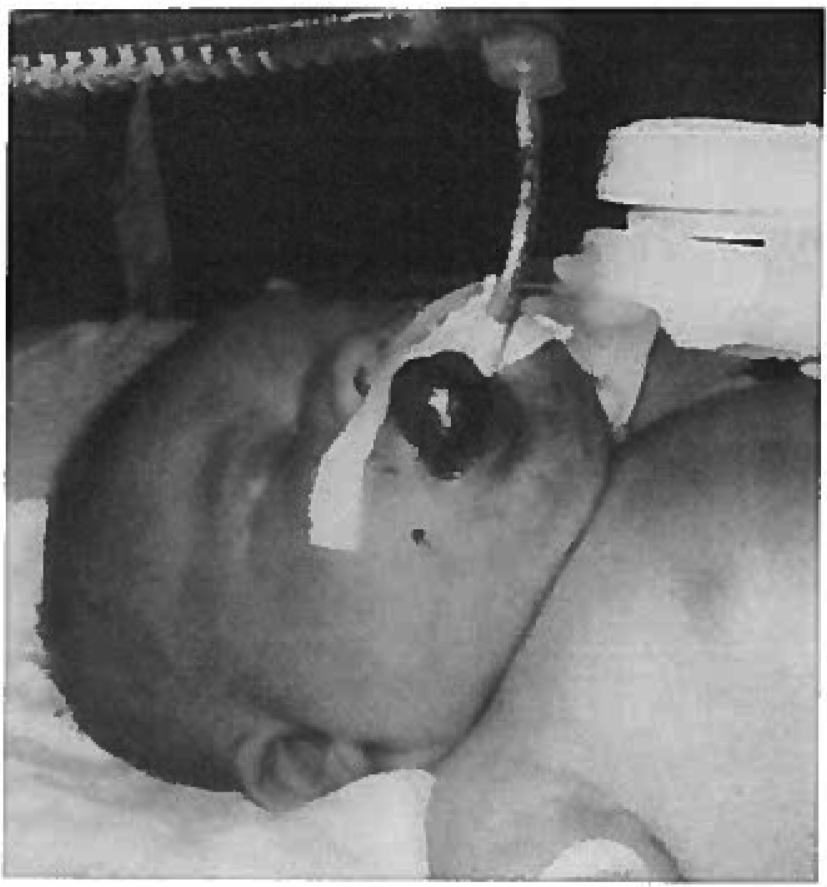

Figure 2 Intubated infant with lobulated mass protruding from the mouth.

was performed to rule out intracranial extension, and was normal. For further diagnostic evaluation and exclusion of subtle intracranial extension, a computed tomography scan of the head and face was performed, confirming a lobulated $3 \times 4-\mathrm{cm}$ soft tissue mass arising from the right maxillary alveolar ridge, without cystic areas or calcification (Fig. 3). There was no erosion or alteration of the adjacent dental structures. The mass extended anteriorly to protrude through the mouth, but the tongue and mandible were intact. No intracranial extension was noted.

Surgical excision was performed on day 1, without complication. The infant was extubated on the first postoperative day had a normal respiratory effort. The postoperative course was uneventful, and the infant was discharged on day 3 .

Pathologic evaluation of the specimen showed no areas of cystic change, hemorrhage, or necrosis. Microscopic examination revealed a benign tumor composed of large cells with granular cytoplasm and rare islands of odontogenic epithelium. The findings were representative of a benign congenital gingival granular cell tumor.

\section{DISCUSSION}

Congenital intraoral tumors are rare lesions. By far the most commonly described is a teratoma (epignathus), which usually arises from the oral cavity or pharynx. ${ }^{1-5}$ Teratomas arising in or near the oropharynx are seen on US as solid masses often with areas of calcification and cystic change. The differential diagnosis for a mass arising in or near the mouth on a prenatal ultrasound should include teratoma, hemangioma, lymphangioma

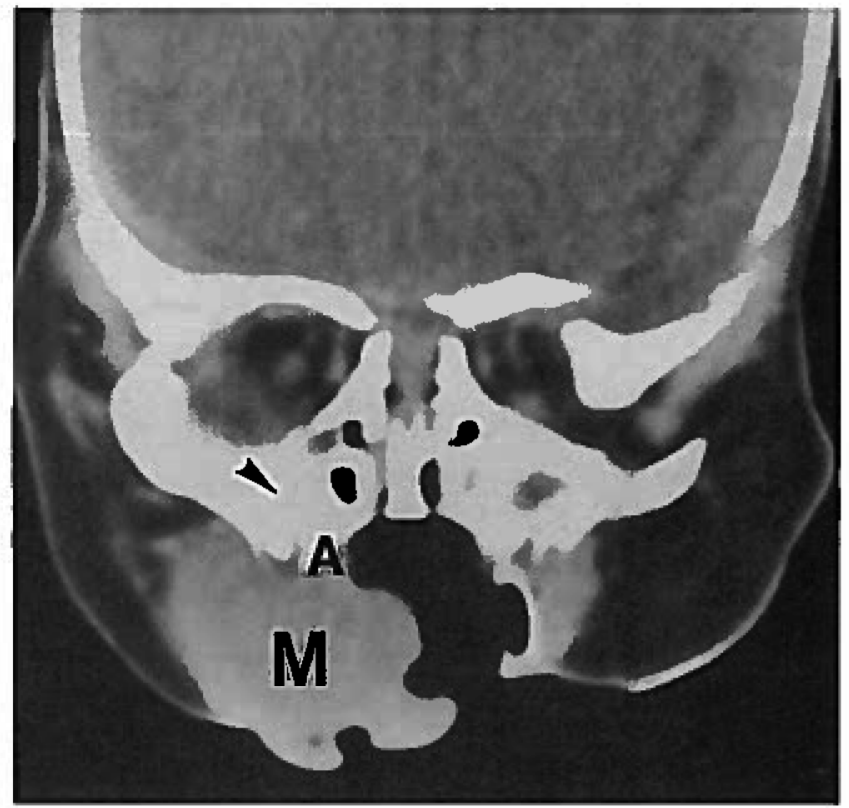

Figure 3 Coronal computed tomography scan through the face shows a lobulated soft tissue mass (M) extending from the right superior alveolar ridge (A). Arrowhead indicates a small tooth bud.

(cystic hygroma), fibrous tumor, neurofibroma, and granular cell tumor. Hemangiomas may be solid or cystic but arise from the subcutaneous tissues externally. ${ }^{6}$ Pulsations may be seen in the vascular spaces on real-time US, ${ }^{7}$ and Doppler may be an effective way to evaluate the blood flow. Lymphangiomas are predominantly cystic on US and tend to originate posteriorly in the neck. ${ }^{\mathrm{B}-10}$ There is one report of a fibrous tumor arising from the floor of the mouth ${ }^{11}$ but this did not extend externally. Facial neurofibromas are subcutaneous tumors with localized nodular or diffuse soft tissue involvement, but are not pedunculated. ${ }^{12}$

Congenital gingival granular cell tumor (congenital epulis) has been previously described in the literature in newborns, ${ }^{13-17}$ but only twice antenatally. ${ }^{17,18}$ It is a benign soft tissue tumor that usually arises from the maxillary alveolar ridge anteriorly. The tumor can be pedunculated or broad based and is covered by smooth, nonulcerated mucosa. Microscopically, large sheets of granular cells and remnants of odontogenic epithelium are seen. While these tumors may regress spontaneously, ${ }^{14,19,20}$ surgical resection is usually employed. There are no reports of postsurgical recurrence. ${ }^{20.21}$ Congenital gingival granular cell tumor is found in the neonate, predominantly in females, and is closely related histologically to the granular cell tumor of older children and adults. The latter, however, has no sex predilection and can be found in many anatomic sites (skin, gastrointestinal tract, respiratory tract). While the histologic origin of both of these granular cell tumors is unknown, they are identical on 
light microscopy, but can be differentiated by immunochemistry and electron microscopy evaluation..$^{22-24}$

The prenatal evaluation of any fetal mass involving the head and neck should include assessment of the amniotic fluid. Polyhydramnios suggests an obstructive component to the gastrointestinal tract that could also involve the respiratory tract at birth, leading to respiratory compromise. While no polyhydramnios was present in our case, prudence dictated elective cesarean section delivery under controlled circumstances to allow for optimal handling of the neonatal airway prior to preoperative evaluation for the definitive surgery.

\section{REFERENCES}

1. Abiose BO, Akingbehin NA, Marinho AO: Epignathus: A report of two cases and a review of literature. E African Med J 65:60, 1988

2. Faerber TH, Hiatt WR, Dunlap C: Congenital teratoid cyst of the floor of the mouth. Oral Maxillofac Surg 487, 1988

3. Chervenak FA, Tortora M, Moya FR, et al: Antenatal sonographic diagnosis of epignathus. J Ultrasound Med 3:235, 1984

4. Kang KW, Hissong SL, Langer A: Prenatal ultrasonic diagnosis of epignathus. JCU 6:330, 1978

5. Keswani RK, Chugh TD, Dhall JC, et al: Epignathus-a case report. Br J Plast Surg 21:355, 1968

6. Meizner I, Bar-Ziv J, Holcberg G, et al: In utero prenatal diagnosis of fetal facial tumor-hemangioma. JCU 13:435, 1985

7. Pennell RG, Baltarowich O: Prenatal sonographic diagnosis of a fetal facial hemangioma. I Ultrasound Med 5:525, 1986

8. Sheth S, Nussbaum AR, Hutchins GM, et al: Cystic hygromas in children: Sonographic pathologic correlation. Radiology 162:821, 1987

9. Callen PW: Ultrasonography in Obstetrics and Gynecology. Philadelphia, PA, WB Saunders, 1988, p 217
10. Rahmani MR, Fong KW, Connor RP: The varied sonographic appearance of cystic hygromas in utero. J Ultrasound Med 5:165, 1986

11. Takagi M, Ishikawa G: Fibrous tumor of infancy: Report of a case originating in the oral cavity. J Oral Pathol 2:293, 1973

12. Grabb WC, Dingman RO, O'Neal RM, et al: Facial hamartomas in children: neurofibroma, and hemangioma. Plast Reconstr Surg 66:509, 1980

13. Fuhr AH, Krogh HJ: Congenital epulis of the newborn: centennial review of the literature and a report of case. J Oral Surg 30, 1972

14. Lack EE, Worsham GF, Callihan MD, et al: Gingival granular cell tumors of the newborn (congenital "epulis"). Am J Surg Pathol 5:37, 1981

15. Welburg RR: Congenital epulis of the newborn. $\mathrm{Br} J$ Oral Surg 18:238, 1980

16. Birman EG, Lopes RA, Barbosa J: Abbreviated case report. Congenital epulis. Oral Surg 437, 1972

17. Hoyme HE, Musgrave SD, Browne AF, et al: Congenital oral tumor associated with neurofibromatosis detected by prenatal ultrasound. Clin Pediatr 26:372, 1987

18. Schwartz Z, Katz A, Dreasen E, et al: Case report. Polyhydramnios caused by giant alveolar granular cell myoblastoma. Acta Obstet Gynecol Scand 65:519, 1986

19. O'Brian FV, Pielou WD: Congenital epulis: Its natural history. Arch Dis Child 46:559, 1971

20. Regezi JA, Sciubba J]: Oral pathology: clinical-pathologic correlations. Philadelphia, PA, WB Saunders, 1989, PP 207-210

21. Enzinger FM, Weiss SW: Soft Tissue Tumors. St. Louis, MO: CV Mosby, 1988

22. Kay S, Elizay RP, Wilson MA: Ultrastructural observations on a gingival granular cell tumor (congenital epulis). Cancer 27:674, 1971

23. Lifshitz MS, Flotte TJ, Greco MA: Congenital granular cell epulis. Immunohistochemical and ultrastructural observations. Cancer 53:1845, 1984

24. Monteil RA, Loubiere $R$, Charbit $Y$, et al: Gingival granular cell tumor of the newborn: Immunoperoxidase investigation with anti-S-100 antiserum. Oral Surg Oral Med Oral Pathol 64:78, 1987 